\begin{tabular}{c|c|c|}
\cline { 2 - 3 } CRITICAL & $\begin{array}{l}\text { Western Ghats } \\
\text { EARTNERSHIP FUND }\end{array}$ & Special Series \\
\hline
\end{tabular}

\title{
PARASITOIDS (HYMENOPTERA) OF XYLOPHAGOUS BEETLES (COLEOPTERA) ATTACKING DEAD WOOD IN SOUTHERN WESTERN GHATS, KERALA, INDIA, WITH DESCRIPTIONS OF TWO NEW SPECIES
}

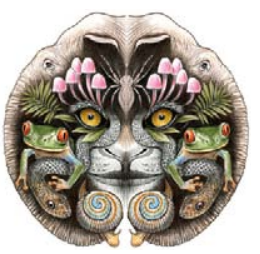

ISSN

Online 0974-7907

Print 0974-7893

OPEN ACCESS

\author{
P.M. Sureshan ${ }^{1}$, T.C. Narendran ${ }^{2} \&$ K. Nikhil ${ }^{3}$ \\ 1,2,3 Zoological Survey of India, Western Ghats Regional Centre, Jafferkhan Colony, Eranhipalam P.O., Kozhikode, \\ Kerala 673006, India \\ ${ }^{1}$ pmsuresh43@yahoo.com (corresponding author), ${ }^{2}$ drtcnarendran@yahoo.com, ${ }^{3}$ kizhakayilnikhil@gmail.com
}

Abstract: An account is given of four species of Hymenoptera parasitoids probably of the wood boring beetle Clytocera chinospila Gahan (Coleoptera: Cerambycidae) from Chinnar Wildlife Sanctuary, southern Western Ghats, Kerala. Two new hymenopteran species, Eurytoma chinnarensis (Eurytomidae) and Foenatopus idukkiensis (Stephanidae) are described. Solenura ania Walker (Pteromalidae) is reported for the first time from Kerala and Western Ghats with a new host record, and Doryctus sp. (Braconidae) is reported here.

Keywords: Eurytoma chinnarensis sp. nov., Eurytomidae, Foenatopus idukkiensis sp. nov., Hymenoptera, new species, parasitoids, Stephanidae, xylophagous beetles.

Abbreviations: AOL - Distance between a posterior ocellus and the anterior ocellus; CC - Costal cell; F1-F5 - Funicular segments 1 to 5; LLength; $\mathrm{m}$-cu - Transverse medio-cubital vein; MV - Marginal vein; OOL - Ocellocular distance; PGA - Pterostigma; PMV - Postmarginal vein POL - Post-ocellar distance; $r$ - Transverse radial cell; SMV - Submarginal vein; $1-S R+M$ - Marginal cell sectio radii Media; 2SR - Submarginal cel Sectio radii; 3-SR - Discal cell Sectio radii; SR1 - Sectio radii Margina cell; STV - Stigmal vein; T1-T7 - Gastral tergites 1-7; W - Width; ZSIK Zoological Survey of India, Western Ghat Regional Centre, Kozhikode, Kerala, India.
The coleopteran (Insecta) families Cerambycidae, Buprestidae, Scolytidae, Anobiidae, Passalidae, Lucanidae and Elateridae mainly include wood boring beetles. Insect parasitoids exert natural control of the populations of wood boring beetles by attacking their immature stages. Major insect parastoids attacking the wood boring beetles belong to Hymenoptera (Chalcidoidea, Stephanoidae, Ichneumonoidea, Proctotrupoidea, Megalyroidea, Evanoidea, Chrysidoidea and Vespoidea). During the faunal exploration surveys conducted in the forest tracts of Chinnar Wildlife Sanctuary, Kerala $\left(10^{\circ} 30^{\prime} \mathrm{N}\right.$ \& $77^{\circ} 17^{\prime} \mathrm{E}$; altitude $\left.450 \mathrm{~m}\right)$, a piece of dead wood of an unidentified forest tree heavily infested with xylophagous beetles was collected. The infestation of beetles in the wood was indicated by closely arranged holes and saw dust (Image 18). One hymenopteran parasitoid, Solenura ania (Walker) (Hymenoptera: Pteromalidae)

DOI: http://dx.doi.org/10.11609/JoTT.o3385.4385-91 | ZooBank: urn:Isid:zoobank.org:pub:736C81FA-5593-4ED6-A37D-54D4E5511721

Manuscript details: Ms \# 03385 | Received 13 October 2012 | Final received 03 May 2013 | Finally accepted 08 May 2013

Citation: P.M. Sureshan, T.C. Narendran \& K. Nikhil (2013). Parasitoids (Hymenoptera) of xylophagous beetles (Coleoptera) attacking dead wood in southern Western Ghats, Kerala, India, with descriptions of two new species. Journal of Threatened Taxa 5(9): 4385-4391; http://dx.doi.org/10.11609/JoTT.03385.4385-91

Copyright: ( ) Sureshan et al. 2013. Creative Commons Attribution 3.0 Unported License. JoTT allows unrestricted use of this article in any medium, reproduction and distribution by providing adequate credit to the authors and the source of publication.

Funding: The work is based on the annual research programme of Zoological Survey of India, WGRC, Calicut (Ministry of Environment \& Forests, Govt.of India).

Competing Interest: None.

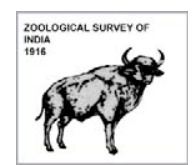

Acknowledgements: We are grateful to Dr. K. Venkataraman, Director, Zoological Survey of India, Kolkata for providing facilities and encouragement. We are grateful to Dr. H.V. Ghate, Modern College, Pune, for identifying the beetle specimens, Dr. Sheeba, Assistant Professor, NSS College, Manjeri, Kerala, for identifying the braconid specimens, Dr. K. Rajmohana, Scientist C and Mr. Bijoy, C. SRF, Zoological Survey of India, and Western Ghat Regional Centre, Kozhikode, for providing some specimens of Eurytomidae for our studies and the help rendered in taking photographs. TCN is grateful to the Ministry of Environment and Forests, Government of India, for a grant under AICOPTAX programme. Thanks are also due to the Chief Wildlife Warden, Kerala, and the forest officials of Chinnar Wldlife Sanctuary for granting the permission for faunal collection and help rendered during the field work.

The publication of this article is supported by the Critical Ecosystem Partnership Fund (CEPF), a joint initiative of l'Agence Française de Développement, Conservation International, the European Commission, the Global Environment Facility, the Government of Japan, the MacArthur Foundation and the World Bank. 
(Image. 17) was collected from the surface of the wood by aspiration. The wood was then cut into small pieces and kept in wide-mouthed glass bottles covered with mulmul cloth. The hymenopteran parasiotids emerged from the wood along with an adult beetle Clytocera chinospila Gahan (Coleoptera: Cerambycidae), that were subsequently identified as Eurytoma chinnarensis sp. nov. (Eurytomidae), Foenatopus idukkiensis sp. nov. (Stephanidae) and Doryctus sp. (Braconidae). Among the individual parasitoids that emerged, the number of Solenura ania was at a maximum. The beetle Clytocera chinospila Gahan (Cerambycidae) was identified as a new host for Solenura ania which is reported for the first time from the southern Western Ghats. The specimens of the present study are deposited in Zoological Survey of India, Western Ghat Regional Centre, Kozhikode (ZSIK). The terminology used in the paper follows that of Bouček (1988) for Chalcidoidea, Achterberg (2002) for Stephanoidea and Belokobylskij et al. (2004) for Braconidae.

\section{Descriptions of Parasitoids}

Order: Hymenoptera

Superfamily: Chalcidoidea

Family: Eurytomidae

Subfamily: Eurytominae

\section{Eurytoma chinnarensis Narendran \& Sureshan sp. nov. (Images 1-7)}

urn:Isid:zoobank.org:act:1A0D5DCB-6617-4CF4-A4EC-35B3DE9ABB06

Material examined: Holotype: Reg.No. ZSI/WGRC/ IR/INV/2349, 04.iv.2012, female, Kuttar, Chinnar Wildlife Sanctuary, Idukki District, Kerala, India, $10^{\circ} 30^{\prime} \mathrm{N}-77^{\circ} 20^{\prime} \mathrm{E}$, altitude $450 \mathrm{~m}$, emerged from dead wood infested with beetles, coll. P.M. Sureshan.

Paratypes: ZSI/WGRC/IR/INV/2350 (i-ix), 9 females, data same as that of holotype; ZSI/WGRC/IR/INV 2351, 1 female, data same as that of holotype except coll. $\mathrm{K}$. Rajmohana.

Female: (Holotype). Length: $2.75 \mathrm{~mm}$. Body black except scape, pedicel, maxillary and labial palps, trochanters, bases and apices of femora, tibiae completely, tarsi and ovipositor yellow; F1, F2, F3 and ventral part of gaster brownish-yellow; F4, F5 and clava brownish-black; ventral surface of cervix pale brownish-yellow; frons and mesosoma with reddish-brown marks (Images.2,4); fore coxae black with sides partially brown; mid and hind coxae pale reddish-brown; femora dark brown medially (Image 1); eyes grey; wings hyaline, veins pale brown; pubescence on body silvery.
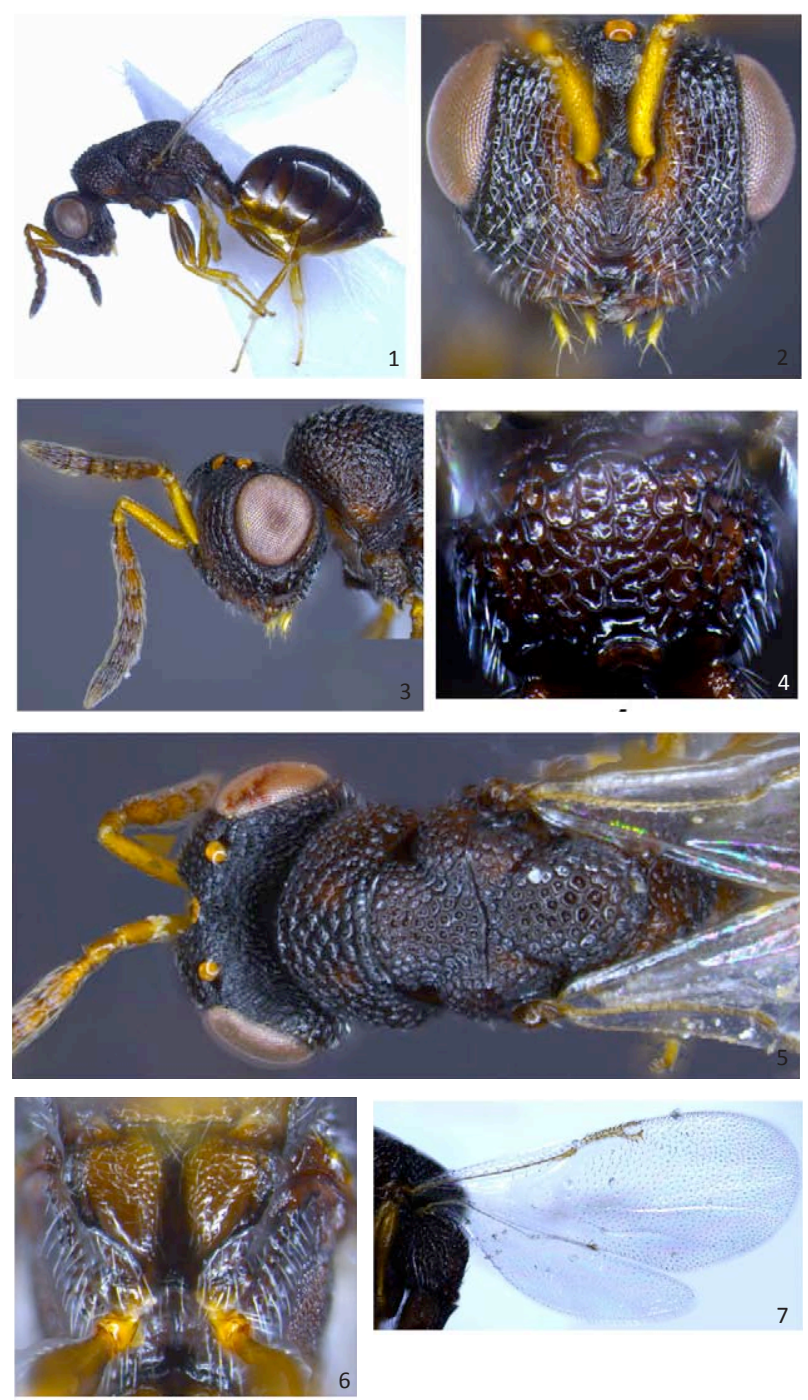

Images 1-7. Eurytoma chinnarensis Narendran \& Sureshan sp. nov. Female: 1 - Body in profile; 2, Head in dorsal view; 3 - Head and antenna in profile; 4 - Head and mesosoma in dorsal view; 5 - Propodeum in dorsal view; 6 - Fore coxae in ventral view; 7 - Wings. (C) WGRC, ZSI, Calicut

Head: (Image 2-4) width in anterior view 1.43x its height (77:54); width in dorsal view 1.97x its length (75:38); POL: OOL:AOL=24:6:10; anterior ocellus situated outside scrobe; scrobe with raised reticulation; frons with close pits, interstices carinate; scrobal margin carinate laterally; area below toruli with a ' $\mathrm{V}$ ' shaped carina (Image $2)$; clypeus smooth and shiny, apex entire; mandibles bidentate; genal carina well developed; postorbital carina faintly indicated; malar sulcus distinct with a patch of faintly reticulated shiny area just below ventral margin of eye. Antennae inserted a little above the level of ventral margin of eyes; antennal formula (excluding radicula) 11153; scape reaching just above anterior ocellus; ratio of L:W of antennal segments: Radicula 2:3; scape 30:7; 
pedicel 8:6; F1 14:6; F2 11:7; F3 11:7; F4 8:8; F5 10:7; clava 20:9. F1 slightly narrowed basally with a single row of longitudinal sensillae.

Mesosoma: (Images 4,5) Relative L: W of mesosoma 118:135; mesoscutum 30:60; scutellum 38:36; propodeum 37:45. Pronotum with interstices of pits spiny (Image 3) (clearly visible in side view); propleuron subtriangular; prosternum triangular, posterior margin slightly biconcave with slight median projection, concavity with a row of 5-6 weak setae along anterior margin, procoxa two-thirds from base to apex depressed ventrally (Image 6) for reception of lower head (postgenal carina), depression strongly carinate along outer edge (Image 3) forming a sharp tooth in side view; mesopleuron and mesepisternum in ventral view with semicircular carinae meeting medially and protruding forwards between forecoxae; mesosternal shelf flat, wider than mesocoxal diameter; prepectus subtriangular with posterior margin arcuate, surface reticulate punctuate. Propodeum (Image 5) with distinct close pits, median area slightly and broadly concave with an arch like carina at basal median part ; spiracle longer than wide (4:3), separated from posterior margin of metanotum by a distance longer than length of spiracle. Hind coxa reticulate punctuate on dorso-lateral part. Relative L: W of hind coxa 34:17; hind tibia 49:7. L of first hind tarsal segment: second hind tarsal segment 21:5. Hind tibia with two apical spurs and more than 15 spine like setae on dorsal margin. Forewing (Image 7) 2.4x as long as its width (187:78); SMV with 7-9 dorsal setae; basal one-third of forewing mostly asetose; relative length of CC 79; SMV 66; PGA 15; MV 24; PMV 11; STV 13.

Metasoma: Metasoma (Image 1) longer than mesosoma (155:118) (petiole L 23+ gaster L 132); petiole 2.6x as long as wide (23:9); closely pitted; posterior ventrolateral distal part carinate (with 10-12 longitudinal carinae). Relative dorsal length of gastral tergites, T1 48; T2 11; T3 29; T4 29; T5 27; T6 9; T7 5.5; ovipositor sheath 5.3.

Male: Unknown.

Host: Emerged from dead wood heavily infested with the beetle Clytocera chinospila Gahan (Coleoptera: Cerambycidae).

Etymology: The species name is after the collection area Chinnar Kerala.

Variation: Females vary in length $1.87-3 \mathrm{~mm}$. The reddish-brown marks on mesosoma and legs become black in some paratypes, coxae and femora become more blackish and the tibiae with brownish tinge medially. When the ovipositor is tilted upwards in some paratypes the length of gastral segments is shortened.
Remarks: Eurytoma chinnarensis sp. nov. runs to couplet number 5 of the key to species of Eurytoma of Indian sub-continent by Narendran (1994) but does not go readily beyond the first couplet because of the presence of several (more than 15) dorsal spine like setae in a row on the hind tibia. Ignoring this character, Eurytoma chinnarensis sp. nov. will come to Eurytoma quadrispina Narendran and Eurytoma pentaspina Narendran, but differs from these species in having: (i) interstices of pronotum spiny (in E. quadrispina and $E$. pentaspina interstices of pronotum not spiny); (ii) T3 and T4 equal in dorsal length and largest (in E. quadrispina and E. pentaspina T4 largest and 1.75 to $1.77 x$ as long as T3). Besides these antennal segments also differ in relative proportions.

Eurytoma chinnarensis sp. nov. resembles Eurytoma dentata Mayr, Eurytomachaitra Narendran, E. punctigastra Narendran and Eurytoma nalanda Narendran in having fore coxa with a tooth (coxal depression) in lateral view but the new species differs from all these species in having: (i) pronotum with short spine like interstices, (ii) hind tibia with more than 15 spine like setae on dorsal margin, metasoma with a long petiole $(0.7 x$ length of hindcoxa, 23:34) and in different proportions of antennal segments and gastral tergites. This new species also resembles E. xylophaga Yang (1996) in having: (i) F1 relatively long (ii) in facial and pronotal sculture (iii) in having scape with reticulation. However it differs from $E$. xylophaga in having gaster not compressed, elongate and subrounded with ovipositor sheath not protruding, POL $4 \times \mathrm{OOL}$ (in xylophaga gaster compressed, not subrounded and ovipositor sheath protruded, and POL 3.4x OOL ). E. chinnarensis sp. nov. does not come near any other old world species listed by Noyes (2012).

Superfamily: Stephanoidea

Family: Stephanidae

Foenatopus idukkiensis Sureshan \& Narendran sp. nov. (Images 8-14)

urn:Isid:zoobank.org:act:D7057220-4D56-4EEB-A07B-B1DD70442630

Material examined: Holotype: ZSI/WGRC/IR/ INV/2346, 04.iv.2012, female, Kuttar, Chinnar Wildlife Sanctuary, Idukki District, Kerala, India, $10^{\circ} 30^{\prime} \mathrm{N}-77^{\circ} 20^{\prime} \mathrm{E}$ altitude $450 \mathrm{~m}$, emerged form dead wood infested with beetles, coll. P.M. Sureshan.

Paratypes: ZSI/WGRC/IR/INV/2347, 1 female, data same as that of holotype; ZSI/WGRC/IR/INV/2348 (i-ii), 2 males, data same as that of holotype.

Female: (Holotype): Body Length $11 \mathrm{~mm}$; terebra 

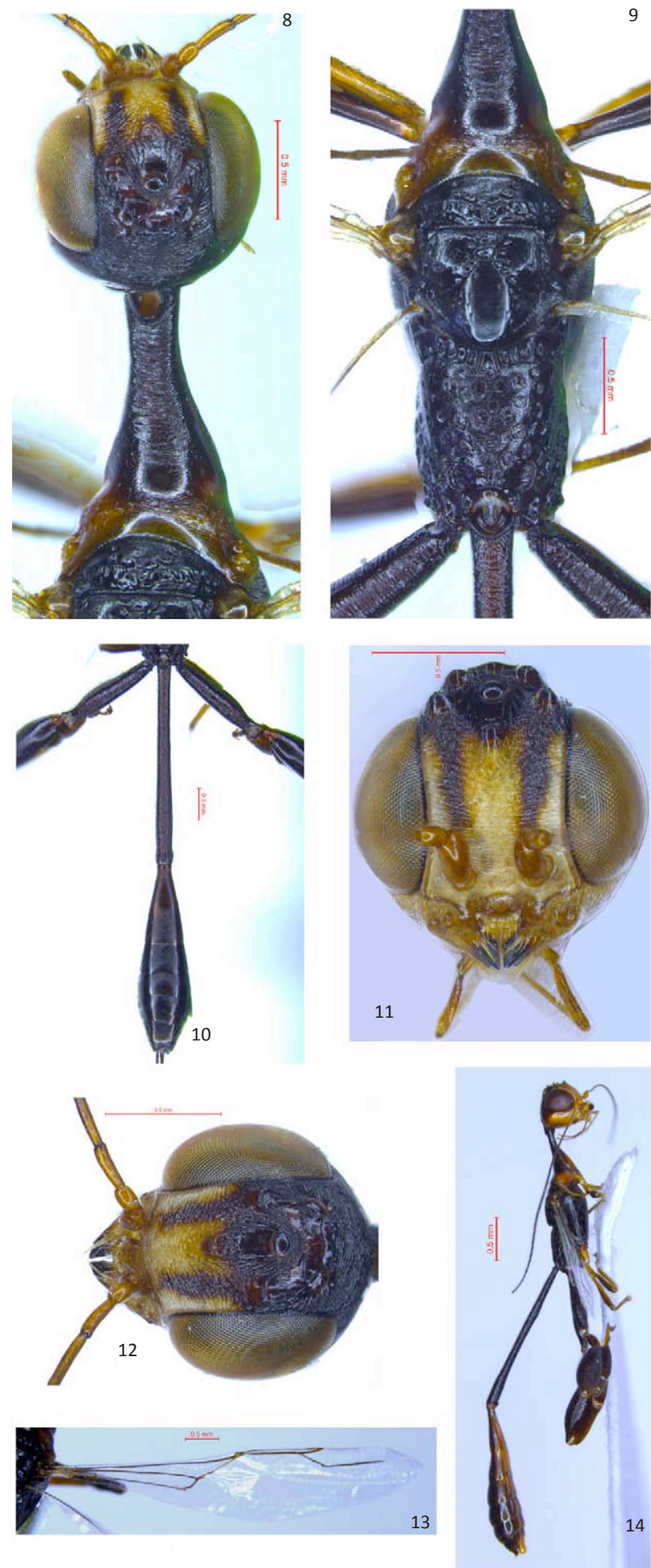

Image 8-14. Foenatopus idukkiensis Sureshan \& Narendran sp. nov. Female: 8 - Head and pronotum in dorsal view; 9 - Mesosoma dorsal view; 10 - Metasoma and part of hind legs dorsal view; 11 - Head front view; 12 - Head dorsal view; 13 - Fore wing; 14 - male body in profile. (C) WGRC, ZSI, Calicut
$10 \mathrm{~mm}$. Colour: body blackish brown with following parts as follows: face upto front ocellus yellow with two longitudinal brown bands starting from toruli, parallel to eye margin reaching upto coronal teeth; gena of same colour reaching upto upper level of eye; mouth parts yellowish-brown except tips of mandible black. Antennae with radicula, scape and pedicel testaceous, remaining segments brown; ocelli concolorous with body; eyes brassy brown; ventral and posterior-dorsal part of pronotum and tegula testaceous; tibiae and tarsi testaceous, larger spines of hind femora white, fore and mid coxae, middle tibiae and tarsi mostly testaceous; gaster ventrally testaceous, terebra with a subapical white band.

Head: (Images. 8, 11, 12) in dorsal view width $1.1 \mathrm{x}$ length, vertex distinctly trans-straite carinate, ocellar area obliquely striate; posterior margin of head sharply bordered. Head width in anterior view 1.5x distance between front ocellus and lower margin of clypeus; eye length $1.34 \mathrm{x}$ width in profile; area between upper margin of toruli and front ocellus transversely striatecarinate, interstices finely reticulate, area below toruli finely reticulate, gena shiny; three anterior coronal teeth large, lobe shaped, both posterior ones small and part of transverse lamella widened at both end, after this lamella four strong complete regular lamelliform and more or less straight carinae (third one curved), followed by distinct transverse striae, which ends little above occipital carina; area inside the coronal teeth with longitudinal carinae with interstices finely reticulate, almost shiny; temples smooth and shiny; occipital carina distinct. Antennae with 30 segments. Relative lengths of scape, pedicel, first, second and third flagellar asegments as 16, 8, 14.5, 21.5, 23.5 .

Mesosoma: (Images 8,9) pronotal neck anteriorly distinctly concave, anterior and middle part distinctly transverse reticulate, posterior part finely reticulate, posterior marginal area smooth and shiny, ventrally with a median carina throughout the length and carinae on ventro lateral margins. Posterior part of pronotum distinctly differentiated from middle part, ventral part uniformly and moderately reticulate. Mesoscutum with a broad transverse band of broad pits in the posterior half, anterior half finely and transversely reticulate; axillae separated by a large median pit which is divided into two by a transverse carina, axillae finely but distinctly and longitudinally reticulate. Median part of scutellum with fine aciculations and with sparse small pits on sides. Mesospleuron with dense and closely set white pubescence in the anterior half, very finely reticulate with scattered pits on other regions. Metapleuron with a deep 
pit in the anterior part followed by 5-6 transverse carinae distally. Propodeum with broad and shallow pits dorsally and deep and broad pits laterally, interstices distinctly reticulate. Hind coxae strongly annulate carinate, hind femora length subequal to hind coxal length and $2.8 \mathrm{x}$ its width, ventral margin with two large teeth, base with two tubercles, interspace between the large teeth with three small denticles, hind tibia $1.13 x$ as long a hind femur, gradually widened sub medially, inner distal part with many bristly setae. Relative dorsal lengths of pronotum 35, mesoscutum 7.5, scutellum 14.5 , propodeum 26.5 .

Metasoma: (Image.10) Petiole uniformly annulate carinate, length 1.1 xs as long as post petiolar segments. Relative lengths of petiole 88.5, postpetiolar segments combined 86.5 , terebra $1.52 x$ as long as rest of gaster, first tergite $2 x$ as long as its maximum width, hind margin straight, basal part with 3-4 transverse carinae remaining area finely granulate reticulate dorsally and shiny ventrally, hind margin of remaining tergites concave, all tergites similarly sculptured as on first tergite. Forewing venation as in Imageure 13.

Male: (Image 14) length 9mm. Resembles female but differs in colour of face which is uniformly yellow below front ocellus, antennal segments up to fourth flagellar segment, mouth parts except tip of mandible, fore and mid legs including coxae, hind femora basally, tarsi except last segment, distal and ventro lateral parts of pronotum golden yellow, gaster with posterior margin of all tergites straight. Antennae with 26 segments.

Etymology: The species name is after the Idukki District of Kerala, where the specimens were collected.

Variation: Length of female varies between 10.3-11 $\mathrm{mm}$ and male between 6.1-9 $\mathrm{mm}$.

Remarks: In the key to Foenatopus species of Indian subcontinent given by Narendran et al. (2001), this species runs to couplet five and resembles $F$. jodhpurensis Narendran in having hind femur with two large teeth, terebra shorter than body, vertex with two distinct carinae between hind ocelli, etc but differs from it in not having a medina fovea on posterior half of pronotum, propodeum without longitudinal fovea, terebra $0.93 x$ length of body with a distinct subapical white band and different sculpture of the body (in jodhpurensis, pronotum with a median fovea on posterior half, propodeum with a longitudinal fovea, terebra $0.73 x$ length of body without sub apical band and different sculpture on vertex, mesoscutum and propodeum).

In having petiole distinctly longer than rest of metasoma, hind femur with two large teeth and terebra with subapical white band this species resembles F. indicus (Westwood) but distinctly difers from it in having different body sculpture, terebra shorter than body, occiput without small longitudinal depression. This species also resembles F. frontilenea (Morley) (=Diastephanus frontilenea) in having hind femur bidentate, petiole longer than combined length of postpetiolar segments, terebra shorter than body with subapical white band, body length and similar body colour but differs from frontilenea in general sculpture of the body which is more coarse, antenna with first and second flagellar segments not equal in length (in frontilenea body sculpture more fine on frons, vertex, occiput and propodeum antenna with first and second flagellar segment equal in length).

Superfamily: Ichneumonoidea

Family: Braconidae

Subfamily: Doryctinae

\section{Doryctus sp. (Images 15, 16)}

Material examined: ZSI/WGRC/IR/INV/2344 (i-iii), 04.iv.2012, 3 females: Kuttar, Chinnar Wildlife Sanctuary, Idukki District, Kerala, India, $10^{\circ} 30^{\prime} \mathrm{N}-7^{\circ} 20^{\prime} \mathrm{E}$ altitude $450 \mathrm{~m}$, emerged from dead wood infested with beetles, coll. P.M. Sureshan; ZSI/WGRC/IR/INV/2345 (i-v), 5 males, data same as above.
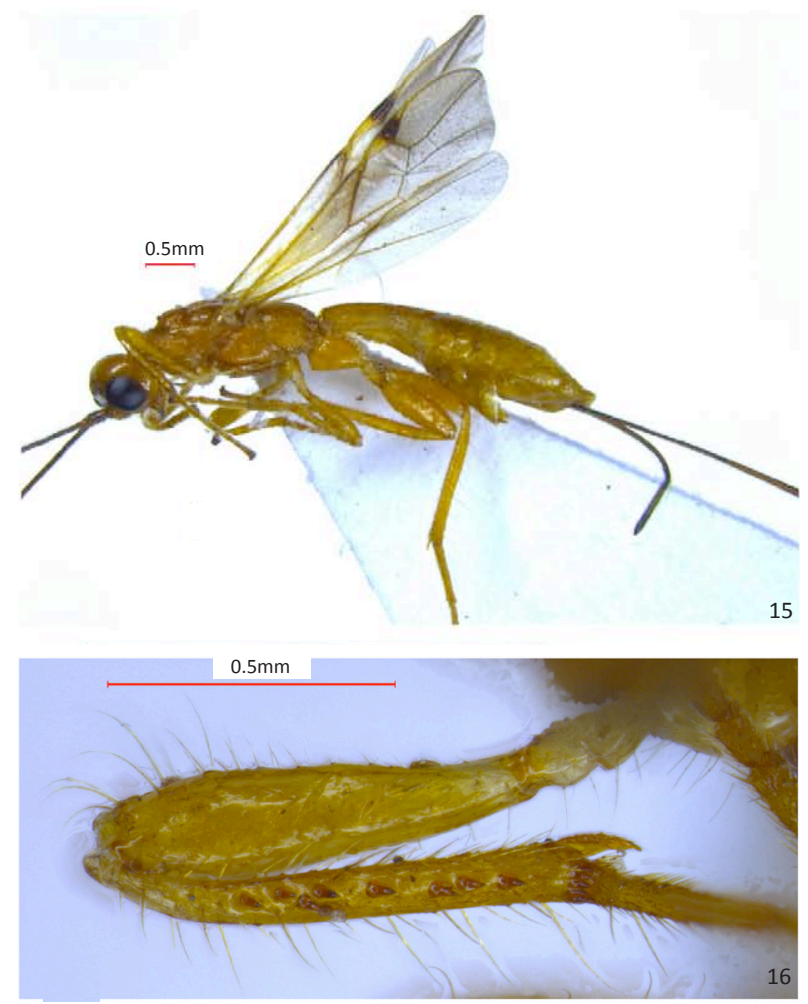

Images 15-16. Doryctus sp. Female: 15 - Body in profile; 16 - Fore femora and tibia. (C) WGRC, ZSI, Calicut 
Diagnosis: Female (Images 15, 16) Length body $5.32 \mathrm{~mm}$, ovipositor $2.74 \mathrm{~mm}$. Head at most very slightly narrower behind eyes than across them; antenna with scape 1.92 as long as its maximum width, third antennal segment $1.3 x$ as long as second segment; vertex, frons, temple and face laterally smooth; face striate medially; sides of ocellar triangle equal; vertex, frons, temple and face with sparse long erect hairs; eyes glabrous, height $1.25 \mathrm{x}$ width; mesoscutum not high, coarsely and sparsely crenulate, notauli shallow, wide, complete; sternaulus shallow, narrow ; scutellem convex, foveate anteriorly, smooth medio-posteriorly; propodeum densely rugulosereticulate with two dorsal carinae posteriorly and without lateral tubercles; fore tibia with strong spines arranged in single row on inner side; forewing $3.9 x$ as long as its maximum width; $r$ raising from middle of pterostigma; 3-RS 1.5x r, 0.03x 3R1, 1.08 x 2-SR; 1 SR+M slightly sinuate; $\mathrm{m}$-cu distinctly antefurcal, as long as 2-SR; hind wing vein $\mathrm{m}$-cu antefurcal; gaster with first tergite slightly narrowed basally, sides slightly widened to apex; length of first tergite $1.30 x$ its maximum apical width; first and second tergites longitudinally striate with rugulosity between striae, remaining tergites weakly rugose.

Remarks: Due to non-availability of relevant literature on the genus and need of more specimens of allied species to compare with, the specimens couldn't be confirmed up to species level. Since Doryctus is a rare braconid genus little known in the oriental region, there is every possibility of these specimens belonging to an undescribed species.

Family: Pteromalidae

Subfamily: Cleonyminae

\section{Solenura ania (Walker) (Image 17)}

1846. Epistenia ania Walker, 93-94. F, Philippines (BMNH)

1961. Solenura ania (Walker): Hedqvist, Ent. Ts. Arg. 90(3): 98. (For further synonymy, see Bouček et al. 1979 and Gibson 2003).

Material examined: ZSI/WGRS/IR-INV-2212 (i-xx), 20 females, ZSI/WGRS/IR-INV-2212 (xxi-xxx), 10 males, 5.iv.2012, Vasyapara, Chinnar Wildlife Sanctuary, Idukki District, Kerala, India, coll. P.M. Sureshan.

Distribution: Oriental region: China, India, Indonesia, Malaysia, Philippines, Taiwan, Thailand; Palearctic Region (China, Japan).

Remarks: The distribution of Solenura ania was extended up to Maharashtra, by the record of the species from Lonar Crater Wildlife Sanctuary, Buldhana District, by Sureshan (2005). The present specimens were reared
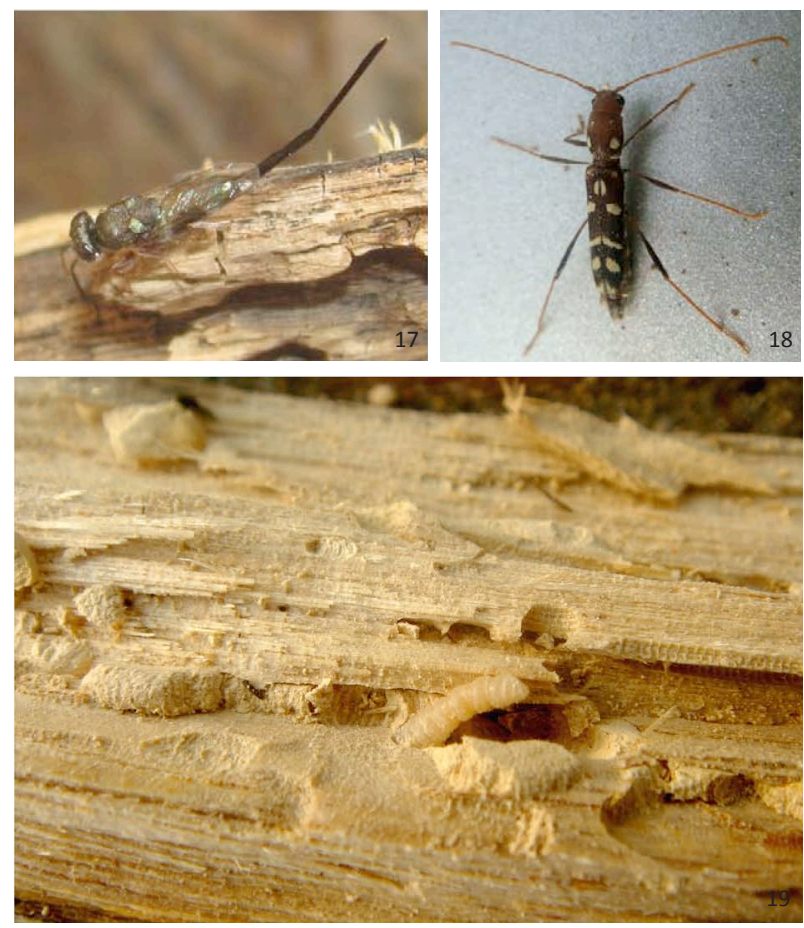

Images 17-19. 17 - Solenura ania (Walker). Female on the dead wood infested with beetles; 18 - The piece of dead wood (cut view) with tunnels of infestation and beetle grub; 19 - Clytocera chinospila Gahan. (C) WGRC, ZSI, Calicut

from the dead wood of a forest tree heavily infested with wood boring beetles Clytocera chionospila, which form the probable host of it (Images 18-19). This is the first record of the species from Western Ghats and Kerala with the new host record. Solenura ania was earlier reared from Chrysobothris succedanea (Buprestidae) and Trichoferus campestris (Cerambycidae) (Gibson (2003). Sureshan (2005) reared the species from dead wood of Ficus sp. infested with Olenocamptus bilobus (Cerambycidae).

\section{REFERENCES}

Achterberg, C. van (2002). A revision of the old world species of Megischus Brulle, Stephanus Jurine and Pseudomegischus gen. nov. with a key to the genera of the family Stephanidae (Hymenoptera: Stephanidae). Zoologische Verhandelingen 339: 206pp.

Belokobylskij, S.A., M. Iqbal \& A.D. Austin (2004). Systematics, Distribution and diversity of the Australian Doryctinae wasps (Hymenoptera: Braconidae: Doryctinae). Records of the South Australian Museum Monograph Series 8: 1-150.

Bouček, Z. (1988). Australasian Chalcidoidea (Hymenoptera). C.A.B. International Wallingford, U.K., 832pp.

Bouček, Z., B.R.S. Rao \& S.I. Farooqi (1979). A preliminary review of Pteromalidae (Hymenoptera) of India and adjacent countries. Oriental Insects 12: 433-468.

Gibson, G.A.P (2003). Phylogenetics and Classification of Cleonyminae (Hymenoptera:Chalcidoidea:Pteromalidae). Memoirs on Entomology, International-Volume 16. Associated publishers, Gainesville, USA, 
339pp.

Hedqvist, K.J. (1969). New genera and species of Diparini with notes on tribe (Hymenoptera: Chalcidoidea). Entomol Ts Arg. 90(3-4): 174-202.

Noyes, J.S. (2012). Universal Chalcidoidea database. http://www.nhm ac.uk/research/curation/research/projects/chalcidoids/database/ detail.dsml?FamilyCode $=J \& V A L G E N U S=$ Eurytoma\&VALSPECIES $=\& V$ ALAUTHOR=Illiger \&VALDATE $=1807 \&$ ValidAuthBracket $=$ false \&TAXO $\mathrm{NCODE}=\& H O M C O D E=0$ \&lastSearchSessionID $=$ Accessed on 12 July 2012

Narendran, T.C. (1994). Torymidae and Eurytomidae of Indian subcontinent (Hymenoptera: Chalcidoidea) - Zoological Monograph. Department of Zoology, University of Calicut, Kerala, 500pp.

Narendran, T.C., K. Rajmohana, T. Jobiraj \& K.A. Karmaly (2001). A taxonomic study of Foenatopus species (Hymenopera: Stephanidae) of Indian subcontinent. Journal of advanced Zoology 22(2): 81-88.

Sureshan, P.M. (2005). New host and distributional records for Solenura ania (Walker) from India and redescription of Solenura feretrius (Walker) (Hymenoptera: Chalcidoidea: Pteromalidae). Records of Zoological Survey of India 105(1-2): 111-116.

Walker, F. (1846). List of the Specimens of Hymenopterous Insects in the Collection of the Bristish Museum - (Part I Chalcidites). London, vii+100pp.

Yang, Z. (1996). Parasitic Wasps on Bark Beetles in China. Science Press. Natural Science Foundation of China, 360pp. 